\title{
Human Bifidobacterium strains as adjunct cultures in Spanish sheep milk cheese
}

\author{
S. Langa, A. Peirotén, P. Gaya, S. Garde, J. L. Arqués, M. Nuñez, M. Medina, and E. Rodríguez-Mínguez* \\ Instituto Nacional de Investigaciones Agrarias y Alimentarias (INIA), Departamento de Tecnología de Alimentos, Ctra. Coruña Km 7 , \\ 28040 Madrid, Spain
}

\begin{abstract}
Three bifidobacteria strains of human origin (Bifidobacterium pseudolongum INIA P2, Bifidobacterium breve INIA P734, and Bifidobacterium longum INIA P678) were used as potential probiotic adjunct cultures for the manufacture of pasteurized sheep milk cheese. Bifidobacteria were inoculated at 5 to $6 \log \mathrm{cfu} / \mathrm{mL}$ in milk vats. Microbiological, physicochemical, rheological, color, and sensory characteristics were determined at 7, 28, and $60 \mathrm{~d}$ of ripening. Counts of $B$. pseudolongum INIA P2 remained above $6 \log \mathrm{cfu} / \mathrm{g}$ during $60 \mathrm{~d}$ of ripening as well as after further simulated gastrointestinal digestion of cheeses. Bifidobacterium breve INIA P734 counts remained stable during $28 \mathrm{~d}$ and decreased by less than 1 log unit after simulated digestion. Bifidobacterium longum INIA P678 counts dropped sharply during cheese manufacture and ripening and were below detection level after simulated digestion. Addition of bifidobacteria strains did not affect starter viability, cheese $\mathrm{pH}$, dry matter, water activity, or salt content but significantly increased overall proteolysis and the concentration of some free amino acids. Cheeses with bifidobacteria exhibited no significant differences in most sensory characteristics with respect to control cheese. According to our results, B. breve INIA P734 and B. pseudolongum INIA P2 are promising candidates as probiotic adjunct cultures in fresh and semi-hard sheep milk cheese.
\end{abstract}

Key words: Bifidobacterium, sensory quality, cheese, microbiome

\section{INTRODUCTION}

After Greece, Spain is the leading country in sheep milk production in Europe. Most sheep milk is processed into mixed-milk cheese varieties because pure

Received January 15, 2020.

Accepted April 26, 2020.

*Corresponding author: minguez@inia.es sheep milk cheese, considered a gourmet product, accounts for only $16.1 \%$ of overall Spanish cheese production (Pulina et al., 2018).

Cheese is a fermented food that has historically been an integral part of the human diet and is considered to provide health benefits, which are attributed to metabolic compounds produced by the bacteria responsible for fermentation (Sanlier et al., 2019). Diet is a critical determinant of variation in gut microbial structure and function, outweighing even host genetics (Carmody et al., 2019). The beneficial co-evolution of human-dairy microorganisms is supported by the high survival rates of 2 bifidobacteria strains used in model cheese manufacture under simulated gastrointestinal conditions (Peirotén et al., 2019b). Some strains derived from ancestral or traditional compatible gut healthy microbiota may confer health benefits to humans (Sonnenburg and Sonnenburg, 2019). In this context, incorporation of human bifidobacteria in traditional cheeses offers opportunities to "fertilize" our microbiota and to "re-wild" the industrialized human gut ecosystems (Mills et al., 2019; Sonnenburg and Sonnenburg, 2019).

Bifidobacteria must meet certain technological properties to ensure a minimal viable count $(6 \mathrm{log} \mathrm{cfu} / \mathrm{g})$ in products to exert a therapeutic effect within the host (Boylston et al., 2004; du Toit et al., 2013). Only a few bifidobacteria strains are robust from a technological point of view (Gomes and Malcata, 1999; Ruiz et al., 2011). In this regard, cheeses present advantages as delivery systems due to their buffering ability, fat content, high $\mathrm{pH}$, and anaerobic environment at the core created by the metabolism of lactic acid bacteria within a few weeks of ripening (Ong et al., 2007; Karimi et al., 2011; Reid, 2015). Studies on cheeses with bifidobacteria have focused mainly on probiotic viability and generally have been based on a few commercial strains alone or in combination with lactobacilli or prebiotics (Barbosa et al., 2016; Song et al., 2017; Cuffia et al., 2018).

Ovine milk is particularly interesting for the manufacture of probiotic cheeses with bifidobacteria in that it permits faster growth than cow milk (Kehagias et al., 2008). In addition, ovine milk seems to be better 
for subjects suffering from cow milk allergy (Albenzio et al., 2013).

Addition of probiotic strains may affect cheese flavor, texture, and appearance (Bergamini et al., 2009; Albenzio et al., 2013), and the commercial success of probiotic products ultimately depends on taste and appeal to the consumer (Granato et al., 2010). Cheese technology influences growth and biochemical activity of starter cultures and probiotic strains (Bergamini et al., 2009). Therefore, sensory studies on cheeses manufactured with bifidobacteria are required to ensure the flavor quality of traditional pure ovine cheese.

To our knowledge, this is the first study on semi-hard Spanish sheep milk cheese made with noncommercial strains of bifidobacteria. In this study, 3 Bifidobacterium sp. strains with proven probiotic and technological properties (Rodríguez et al., 2012; Peirotén et al., 2018, $2019 b$ ) were assayed as adjunct cultures. The objectives of this work were to evaluate (1) their survival in sheep semi-hard cheese, (2) their further survival during the passage through simulated gastrointestinal conditions, and (3) their influence on cheese physicochemical and sensory characteristics.

\section{MATERIALS AND METHODS}

\section{Bacterial Strains and Preparation of Inocula}

Bifidobacterium pseudolongum INIA P2, Bifidobacterium longum INIA P678 (CECT 8178), and Bifidobacterium breve INIA P734 (CECT 8179) were from the Instituto Nacional de Investigación y Tecnología Agraria y Alimentaria (INIA) culture collection (Madrid, Spain). Bifidobacterium breve INIA P734 (CECT 8178) and B. longum INIA P678 (CECT 8179) were selected because of their mother-child pair origin (Peirotén et al., 2018) and are considered robust strains from a technological point of view (Peirotén et al., 2019b). Bifidobacterium breve INIA P734 is under patent (Spanish patent P201231747) based on its origin and in vitro antimicrobial properties. Bifidobacterium pseudolongum INIA P2 is a promising probiotic strain that is technologically robust and able to produce enterolignans (Peirotén et al., 2019a).

Bifidobacterium pseudolongum INIA P2 was grown in reinforced clostridial medium broth (Difco, Sparks, $\mathrm{MD}$ ) at $37^{\circ} \mathrm{C}$ for $48 \mathrm{~h}$ in an anaerobic chamber (Whitley DG250, Don Whitley Scientific, Shipley, UK). Then, cells were collected by centrifugation, washed in PBS, and resuspended in milk. Lyophilized concentrated cultures of $B$. longum INIA P678 and B. breve INIA P734 were rehydrated in UHT milk (Pascual, Aranda del Duero, Spain). Microbial counts of the inocula were determined before each experiment. Commercial mesophilic starter culture (Choozit MA 4001 Lyo 5 DCU; Danisco, Laboratorios, Arroyo, Spain) containing MA 016 (Lactococcus lactis ssp. lactis, L. lactis ssp. cremoris, and L. lactis lactis biovar diacetylactis) and TA 054 (Streptococcus thermophilus) was prepared as specified by the manufacturer by resuspending in 200 $\mathrm{mL}$ of UHT milk.

\section{Cheese Manufacture}

Cheeses were made in 2 trials carried out on different days. In each trial, whole sheep milk (Castellana de Ganaderos, Campo Real, Spain) was pasteurized $\left(74^{\circ} \mathrm{C}\right.$ for $20 \mathrm{~s}$ ), cooled to $30^{\circ} \mathrm{C}$, and distributed in four $40-\mathrm{L}$ vats. Progressive heating was applied, and $\mathrm{CaCl}_{2}(40$ $\mathrm{mL}$ of $20 \% \mathrm{CaCl}_{2}$ solution per vat) was added when the milk reached $30^{\circ} \mathrm{C}$. At $33^{\circ} \mathrm{C}, 40 \mathrm{~mL}$ of commercial starter culture, prepared as specified above, was added to each of the 4 vats. Bifidobacteria strains were added to vats as follows: no bifidobacteria to vat 1 (control cheese), B. pseudolongum INIA P2 to vat 2 (INIA P2 cheese), B. longum INIA P678 to vat 3 (INIA P678 cheese), and $B$. breve INIA P734 to vat 4 (INIA P734 cheese). Liquid rennet (5.3 mL of 1:15,000-strength calf rennet per vat; Laboratorios Arroyo, Santander, Spain) was added 20 min later to all the vats. Curds were cut $40 \mathrm{~min}$ after rennet addition and heated at $37^{\circ} \mathrm{C}$ for 20 min. Then, whey was drained off for $30 \mathrm{~min}$ and curds were washed by adding $20 \mathrm{~L}$ of pasteurized tap water to each vat and distributed into cylindrical molds. Four cheeses of approximately $2 \mathrm{~kg}$ were obtained from each vat. Cheeses were pressed overnight at room temperature and $1.5 \mathrm{~kg} / \mathrm{cm}^{2}$ pressure, salted in $150 \mathrm{~g} / \mathrm{L} \mathrm{NaCl}$ solution for $24 \mathrm{~h}$, and ripened at $12^{\circ} \mathrm{C}$ and $83 \%$ relative humidity for $60 \mathrm{~d}$. Cheeses were sampled for analysis at d 7,28 , and 60 .

Microbial determinations were carried out on curd and on cheeses after 7,28 , and $60 \mathrm{~d}$ of ripening. A representative sample $(5 \mathrm{~g})$ of cheese core was diluted in $45 \mathrm{~mL}$ of sterile sodium citrate solution and homogenized for $90 \mathrm{~s}$ in a stomacher 400 (A. J. Seward Ltd., London, UK). Decimal dilutions were prepared in sterile $0.1 \%$ peptone water and plated in duplicate. Bifidobacterium counts were performed on reinforced clostridial medium agar (Difco) supplemented with 50 $\mu \mathrm{g} / \mathrm{mL}$ mupirocin (Oxoid, Basingstoke, UK) and incubated at $37^{\circ} \mathrm{C}$ for $48 \mathrm{~h}$ under anaerobic conditions. When necessary, enrichment was performed by incubating $10 \mathrm{~g}$ of cheese core homogenized in De Man, Rogosa and Sharpe broth (Biolife, Milano, Italy) supplemented with $0.5 \mathrm{~g} / \mathrm{L}$ L-cysteine hydrochloride (Sigma-Aldrich, St. Louis, MO) and $50 \mu \mathrm{g} / \mathrm{mL}$ mupirocin for $48 \mathrm{~h}$ at the same conditions before plating. Thermophilic and mesophilic starter counts in milk and cheese samples were 
determined in M17 agar (Biolife) supplemented with glucose at $0.5 \mathrm{~g} / \mathrm{mL}$ and incubated for $24 \mathrm{~h}$ at 40 and $30^{\circ} \mathrm{C}$, respectively. Total aerobic counts in pasteurized milk were determined on duplicate plates of tryptic soy agar (Oxoid) incubated at $37^{\circ} \mathrm{C}$ for $24 \mathrm{~h}$ under aerobic conditions.

\section{Resistance to Gastrointestinal Conditions}

Microbial resistance to gastrointestinal conditions was determined at d 7, 28, and 60 of ripening. Cheese core $(5 \mathrm{~g})$ was diluted in $45 \mathrm{~mL}$ of buffered solution (PBS; $\mathrm{pH} 3.0$ ) at $37^{\circ} \mathrm{C}$ and homogenized for $90 \mathrm{~s}$. Homogenates were incubated at $37^{\circ} \mathrm{C}$ for $1 \mathrm{~h}$ under anaerobic conditions. Then, a 1-mL sample was added to $9 \mathrm{~mL}$ of bile solution (0.15\%, ox-bile desiccated; Oxoid) and kept at the same conditions for $1 \mathrm{~h}$. Decimal dilutions were made in sterile $0.1 \%$ peptone water and plated in duplicate on reinforced clostridial medium agar (Difco) supplemented with $50 \mu \mathrm{g} / \mathrm{mL}$ mupirocin (Oxoid).

\section{Physicochemical Determinations}

All physicochemical determinations were performed at $\mathrm{d} 7,28$, and 60 of ripening; in addition, cheese $\mathrm{pH}$ was measured at $\mathrm{d} 1$. Cheese $\mathrm{pH}$ was measured in duplicate by means of a Crison $\mathrm{pH}$ meter (model GPL 22, Crison Instruments, Barcelona, Spain) using a penetration electrode (model 52-3.2). Dry matter content was determined in duplicate by drying to constant weight in an oven at $100^{\circ} \mathrm{C}$. Results were expressed as a percentage of DM on total weight.

Water activity was measured using AquaLab Series 3 equipment (Decagon Devices Inc., Pullman, WA). Salt content was determined in duplicate using Quantab chloride titrators (Hach Co., Loveland, CO) according to AOAC (1984). Results were presented as percentage of salt content on total weight.

Cheese proteolysis was determined on duplicate samples using the o-phthaldialdehyde test (Church et al., 1983). Free AA (FAA) were determined on duplicate samples of cheese as described by Krause et al. (1995) with reversed phase HPLC using a Beckman System Gold chromatograph (Beckman Coulter, Brea, CA) after derivatization with 6-aminoquinolyl- $N$ hydroxysuccinimidyl carbamate (Cohen and Michaud, 1993). Results were expressed as milligrams of AA per $100 \mathrm{~g}$ of cheese DM.

Organic acids (orotic, citric, pyruvic, lactic, uric, acetic, propionic, and butyric acids) and sugars (lactose, glucose, and galactose) were extracted from duplicate samples of cheese as described by Bouzas et al. (1991) and determined by HPLC. Extracts $(20 \mu \mathrm{L})$ were injected in duplicate and eluted with $3 \mathrm{mM}$ sulfuric acid at $65^{\circ} \mathrm{C}$ and a flow rate of $0.7 \mathrm{~mL} / \mathrm{min}$ on a 300 $\times 7.8-\mathrm{mm}$ ion exchange column (HPX-87H Aminex) protected by a cation $\mathrm{H}^{+}$Micro-Guard cartridge (BioRad Laboratories, Hercules, CA) in a Beckman System Gold liquid chromatograph (Beckman Coulter). The system was equipped with 2 detectors connected in series, a diode array detector with detection wavelength of $210 \mathrm{~nm}$ for organic acids and a differential refractometer detector module (Knauer, Berlin, Germany) for sugars. Organic acids and sugars were quantified using the external standard method, and the results were expressed as milligrams of organic acid or sugar per $100 \mathrm{~g}$ of cheese DM.

Volatile compounds were extracted by automated solid-phase microextraction using a CTC CombiPal autosampler (Agilent, Palo Alto, CA) and analyzed by GC-MS using HP 6890-MSD HP 5973 (Agilent) equipment as described by Gómez-Torres et al. (2015) with minor modifications. Duplicate 10-g cheese samples were homogenized in an analytical grinder (IKA Labortechnik, Staufen, Germany) with $15 \mathrm{~g}$ of anhydrous $\mathrm{Na}_{2} \mathrm{SO}_{4}$ and $30 \mu \mathrm{L}$ of an aqueous solution of 1,000 $\mu \mathrm{g} / \mathrm{mL}$ cyclohexanone (Sigma-Aldrich) as internal standard. Five grams of this mixture was weighed in a glass vial (20-mL headspace) and equilibrated for $20 \mathrm{~min}$ at $37^{\circ} \mathrm{C}$. Volatile compounds were extracted using a $2-\mathrm{cm}$ $\times \quad 50 / 30-\mu \mathrm{m}$ StableFlex divinylbenzene/carboxen/ polydimethylsiloxane-coated fiber (Supelco, Bellefonte, $\mathrm{PA}$ ) exposed to the headspace for $30 \mathrm{~min}$ at $37^{\circ} \mathrm{C}$. Desorption into the $\mathrm{GC}$ injection port was at $260^{\circ} \mathrm{C}$ for 9.5 min in splitless mode. Chromatographic separation was carried out in a Zebron 100\% polyethylene glycol capillary column $(60 \mathrm{~m}$ long, $0.25-\mathrm{mm}$ internal diameter, $0.50-\mu \mathrm{m}$ film thickness; ZB-WAXplus, Phenomenex, Torrance, CA) with $1 \mathrm{~mL} / \mathrm{min}$ helium flow. The following temperature program was used: 16 min at $45^{\circ} \mathrm{C}$; first ramp $5^{\circ} \mathrm{C} / \mathrm{min}$ to $110^{\circ} \mathrm{C}, 9 \mathrm{~min}$ at $110^{\circ} \mathrm{C}$; second ramp at $15^{\circ} \mathrm{C}$ to $220^{\circ} \mathrm{C}, 5 \mathrm{~min}$ at $220^{\circ} \mathrm{C}$; final ramp to $240^{\circ} \mathrm{C}$ at $10^{\circ} \mathrm{C} / \mathrm{min}$ and 6 min at $240^{\circ} \mathrm{C}$. Mass detection was performed in the scan mode, from 33 to $300 \mathrm{amu}$ at $5.16 \mathrm{scans} / \mathrm{s}$ and ionization by electron ionization at $70 \mathrm{eV}$. Data were collected with the HP ChemStation program (Agilent), and volatile compounds were identified by comparison of spectra with the Wiley 275 library (Wiley and Sons Inc., Weinheim, Germany) and by comparison of their retention times with authentic standards (Sigma-Aldrich). Relative abundances of compounds were calculated as compound peak area $\times$ $300 /$ internal standard peak area.

\section{Color Determinations}

Color determinations were performed at $\mathrm{d} 7,28$, and 60 of ripening using a CM-700 spectrocolorimeter and 
analyzed with Spectramagic NX VA.9 software (Minolta Camera Co., Osaka, Japan). Cheese samples were cut into 1-cm-thick slices. The reference illuminant was D65 (standard daylight), and the observer angle was $10^{\circ}$. Results are expressed as $L^{*}$ (lightness), $a^{*}(-\mathrm{a}$ green to $+\mathrm{a}$ red $)$, and $b^{*}(-\mathrm{b}$ blue to $+\mathrm{b}$ yellow). After the $L^{*}, a^{*}$, and $b^{*}$ measurements were read, the sample was rotated $90^{\circ}$ and read again. This procedure was carried out in quadruplicate. The method of color measurement applied was specular component excluded, where only the diffuse reflectance is measured, which correlates better to the way the observer sees the color of an object (Gómez-Torres et al., 2014).

\section{Textural Determinations}

Textural determinations were performed at d 7, 28, and 60 of ripening. After being kept at room temperature $\left(20-22^{\circ} \mathrm{C}\right)$ for $2 \mathrm{~h}, 6$ cylinder-shaped samples (17 $\mathrm{mm}$ height $\times 17 \mathrm{~mm}$ diameter) from each cheese were compressed to $75 \%$ of their original height using an Instron Compression Tester 4301 (Instron Ltd., High Wycombe, UK) with crosshead and chart speeds of 50 and $500 \mathrm{~mm} / \mathrm{min}$, respectively. Fracturability (breaking force expressed in newtons, N), hardness (work after $75 \%$ compression, expressed in joules, J), and elasticity (apparent elastic module, expressed in newtons per square millimeter, $\mathrm{N} / \mathrm{mm}^{2}$ ) were measured from the compression curves as previously described (del Pozo et al., 1988). Data were analyzed using BlueHill software (BlueHill Materials Testing Software; Norwood, IL).

\section{Sensory Evaluation}

Sixteen trained panelists tasted cheeses at d 7, 28, and 60 of ripening. The descriptive test used was based on the guidelines of Bérodier et al. (1997). Panelists were asked to score cheese appearance, texture, quality and intensity of odor, aroma, and taste on a 0 - to 10-point scale using a horizontal line anchored at the middle, at the left end (lowest $=0$ points), and at the right end (highest $=10$ points). Odor was defined as the olfactory sensation felt directly by the nose. Aroma was defined as the olfactory sensation felt retronasally upon mastication. Panelists were also asked to give a score, on a 0 - to 10-point scale, to the taste notes acidic, bitter, sweet, and salty.

\section{Statistical Analysis}

Statistical analysis of the data was performed using IBM SPSS Statistics 22.0 (IBM Corp., Armonk, NY) by ANOVA using a general linear model, with bifidobacteria strains and ripening time as main ef- fects. Comparison of means was carried out by Dunnett test (bifidobacteria effect with respect to control) and Tukey test (ripening time or bifidobacteria effects) at $P<0.01$.

\section{RESULTS AND DISCUSSION}

\section{Bacterial Counts in Cheese and Resistance to Simulated Gastrointestinal Conditions}

Initial counts of mesophilic and thermophilic commercial starter cultures in milk after inoculation were on average 7.00 and $5.86 \log \mathrm{cfu} / \mathrm{mL}$, respectively. Starter counts in cheese (Table 1$)$ were influenced $(P<0.01)$ by ripening time, according to ANOVA results, but not by addition of any of the Bifidobacterium strains to cheese.

Bifidobacteria levels in inoculated milk were $6.31 \mathrm{log}$ $\mathrm{cfu} / \mathrm{mL}$ for B. pseudolongum INIA P2, $5.01 \log \mathrm{cfu} / \mathrm{mL}$ for B. longum INIA P678, and $5.77 \log \mathrm{cfu} / \mathrm{mL}$ for $B$. breve INIA P734, and their respective counts in curd were $6.56,4.16$, and $5.89 \log \mathrm{cfu} / \mathrm{g}$. Bifidobacterium pseudolongum INIA P2 counts remained constant in cheese until the end of ripening, whereas $B$. breve INIA P734 counts remained stable during the first $28 \mathrm{~d}$ and declined to $4.35 \mathrm{log} \mathrm{cfu} / \mathrm{g}$ after $60 \mathrm{~d}(P<0.01)$. On the other hand, B. longum INIA P678 counts diminished dramatically to $2.38 \log \mathrm{cfu} / \mathrm{g}$ on $\mathrm{d} 7$ and were below detection at the end of ripening.

Bifidobacterium longum INIA P678 had shown satisfactory in vitro technological properties in previous studies (Peirotén et al., 2018, 2019b). However, its low survival in cheese seems to indicate injury during freezedrying and by cheese-making and ripening conditions. Culture viability alone is not an adequate predictor for the strain functionality under adverse conditions, such as in a food product or after a technological process (Saarela et al., 2006; Vinderola et al., 2012). Bifidobacteria viability in cheese was dependent on the strain used, as observed in previous works (Albenzio et al., 2015; Barbosa et al., 2016), and could be influenced by the starter culture, cheese technology, and type of milk. In this study, we tried to maintain cheese $\mathrm{pH}$ above 5.0 by using sheep milk with high mineral content and by washing the curd for partial removal of lactose. In addition, using medium-sized cheeses of approximately 2 $\mathrm{kg}$ would ensure anaerobic conditions for bifidobacteria as previously demonstrated for Clostridium spp. (Ávila et al., 2016). A buffered and anaerobic matrix is crucial for the survival of bifidobacteria.

Digestion of cheeses under simulated gastrointestinal conditions showed high survival rates for $B$. pseudolongum INIA P2 at any time of ripening, with decreases below $0.4 \log$ units in all cases. Bifidobacterium breve 
Table 1. Counts (log cfu/g) of starter cultures and Bifidobacterium sp. strains during cheese ripening and after simulated gastrointestinal conditions (SGIC) ${ }^{1}$

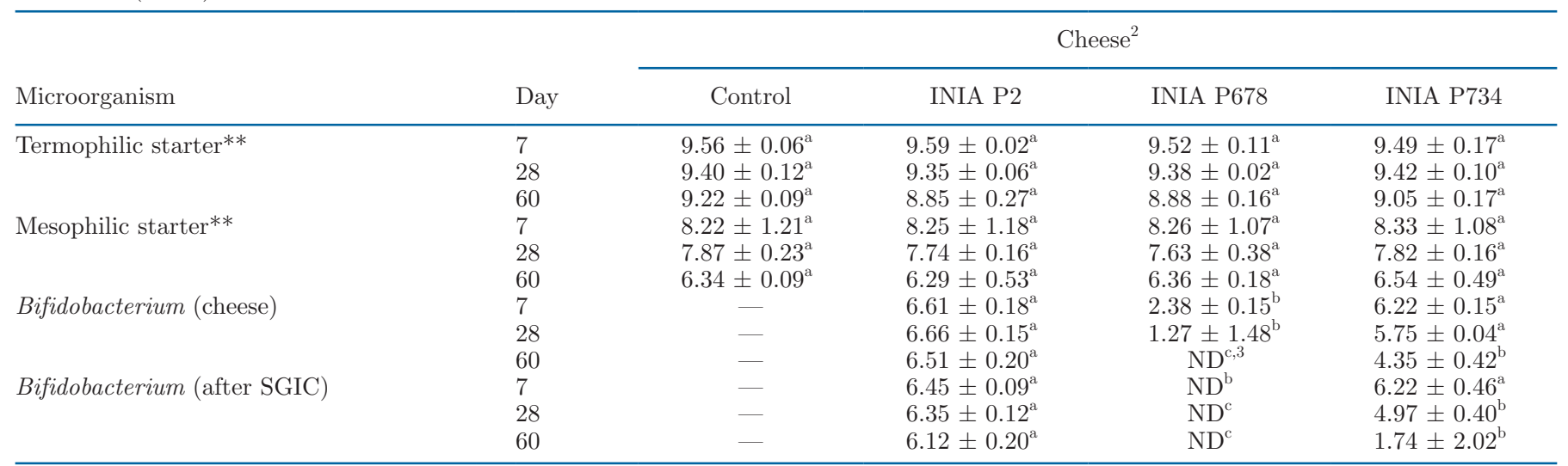

${ }^{\mathrm{a}-\mathrm{c}}$ Means at each ripening time with different superscripts differ significantly $(P<0.01$, Tukey test).

${ }^{1}$ Mean \pm SD of 2 determinations on 2 cheese-making trials.

${ }^{2}$ Initial inoculum of bifidobacteria in milk was $6.31 \pm 0.17 \log \mathrm{cfu} / \mathrm{mL}$ for INIA P2, $5.01 \pm 0.17 \log \mathrm{cfu} / \mathrm{mL}$ for INIA P678, and $5.77 \pm 0.06 \log$ $\mathrm{cfu} / \mathrm{mL}$ for INIA P734.

${ }^{3} \mathrm{ND}=$ below detection level.

**Significant effect $(P<0.01)$ of ripening time.

INIA P734 remained fully viable after digestion of 7-d cheese, decreased by $0.8 \log$ unit in the case of $28-\mathrm{d}$ cheese, and fell sharply, by 2.6 log units, after digestion of $60-\mathrm{d}$ cheese. No digestion assays were performed on B. longum INIA P678 because its counts in cheese were too low or even undetectable.

Bifidobacterium pseudolongum INIA P2 showed a higher resistance in cheese than in previous studies in skim milk (Rodríguez et al., 2012). This fact confirms the protective role of cheese in simulated digestion that may let the strain reach the human colon. To our knowledge, this is the first time that a B. pseudolongum strain has been used for cheese manufacture. Reports on B. pseudolongum isolation from human infant feces or breast milk are scarce (Rodríguez et al., 2012; Souza et al., 2013). However, this species has been described as a widely distributed gut commensal in the animal kingdom, including the human gut, where it could play a beneficial role due to its metabolic activities (O'Callaghan and van Sinderen, 2016; Lugli et al., 2019).

Our results for B. breve INIA P734 and B. longum INIA P678 demonstrated that cheese manufacturing and ripening conditions affected their survival. Injured cells became more sensitive to further gastrointestinal conditions (Collado et al., 2006: Granata et al., 2013). Bile tolerance, and hence resistance to gastrointestinal passage, has been described as strain dependent. In this sense, several genes and proteins conferring bile resistance, which include bile salt hydrolases and bile efflux transporters, were identified and characterized in vitro (Kim et al., 2004; Ruiz et al., 2013). High resistance to these conditions is essential for the probiotic strains to reach the colon and exert the claimed probiotic effect. In this regard, only $B$. breve INIA P 734 in shortripened cheeses and B. pseudolongum INIA P2 even in long-ripened cheeses would meet those criteria.

\section{Cheese Physicochemical Characteristics}

Cheese pH, DM, Water Activity, and Salt Content. Values of $\mathrm{pH}, \mathrm{DM}$, water activity, and salt content (Table 2) were influenced by ripening time $(P<0.01)$ and not by Bifidobacterium addition to cheese according to ANOVA results. Cheese $\mathrm{pH}$ value increased with time of ripening $(P<0.01)$; values were 0.23 to $0.39 \mathrm{pH}$ unit higher on d 60 than on d 1. Dry matter and salt content increased $(P<0.01)$ and water activity values decreased $(P<0.01)$ from d 7 to $\mathrm{d} 60$ of ripening.

Proteolysis and $\boldsymbol{F A A}$. Overall proteolysis was significantly $(P<0.01)$ influenced by Bifidobacterium addition to cheese and by ripening time according to ANOVA results (Table 3 ). Proteolysis values were 5- to 6 -fold higher in 60-d cheeses than in 7-d cheeses. At d 7 , there were no significant differences in proteolysis between cheeses. Proteolysis was higher at d $28(P<$ 0.01 ) for cheese with $B$. longum INIA P678 than for control cheese and at d 60 for cheeses with $B$. longum INIA P678 and B. breve INIA P734 than for control cheese. Cheese with B. pseudolongum INIA P2 did not show differences in proteolysis with respect to control cheese at any ripening time. High cheese $\mathrm{pH}$ values could enhance proteolysis, as the optimum $\mathrm{pH}$ for the 
Table 2. Values of $\mathrm{pH}, \mathrm{DM}$, water activity, and salt content during ripening in control cheese and in cheeses made using bifidobacteria as adjunct cultures $^{1}$

\begin{tabular}{|c|c|c|c|c|c|}
\hline \multirow[b]{2}{*}{ Characteristic } & \multirow[b]{2}{*}{ Day } & \multicolumn{4}{|c|}{ Cheese $^{2}$} \\
\hline & & Control & INIA P2 & INIA P678 & INIA P734 \\
\hline \multirow{3}{*}{$\mathrm{pH}^{* *}$} & 7 & $5.24 \pm 0.10$ & $5.14 \pm 0.07$ & $5.19 \pm 0.12$ & $5.18 \pm 0.08$ \\
\hline & 28 & $5.17 \pm 0.04$ & $5.15 \pm 0.06$ & $5.03 \pm 0.04$ & $5.20 \pm 0.02$ \\
\hline & 60 & $5.42 \pm 0.06$ & $5.35 \pm 0.01$ & $5.45 \pm 0.12$ & $5.30 \pm 0.06$ \\
\hline $\mathrm{DM}^{* *}(\%)$ & 7 & $54.44 \pm 4.12$ & $55.57 \pm 2.27$ & $54.33 \pm 1.06$ & $54.31 \pm 2.10$ \\
\hline \multirow[t]{3}{*}{ Water activity** } & 7 & $0.972 \pm 0.006$ & $0.968 \pm 0.011$ & $0.969 \pm 0.002$ & $0.969 \pm 0.004$ \\
\hline & 28 & $0.960 \pm 0.007$ & $0.958 \pm 0.005$ & $0.959 \pm 0.006$ & $0.959 \pm 0.004$ \\
\hline & 60 & $0.946 \pm 0.003$ & $0.947 \pm 0.007$ & $0.949 \pm 0.003$ & $0.947 \pm 0.005$ \\
\hline \multirow[t]{3}{*}{ Salt** (\%) } & 7 & $1.27 \pm 0.19$ & $1.11 \pm 0.32$ & $1.37 \pm 0.39$ & $1.30 \pm 0.27$ \\
\hline & 28 & $1.68 \pm 0.22$ & $1.65 \pm 0.11$ & $1.61 \pm 0.12$ & $1.78 \pm 0.12$ \\
\hline & 60 & $1.07 \pm 0.31$ & $0.95 \pm 0.01$ & $0.95 \pm 0.00$ & $0.95 \pm 0.01$ \\
\hline
\end{tabular}

${ }^{1}$ Mean \pm SD of 2 determinations on 2 cheese-making trials.

${ }^{2}$ Initial inoculum of bifidobacteria in milk was $6.31 \pm 0.17 \log \mathrm{cfu} / \mathrm{mL}$ for INIA P2, $5.01 \pm 0.17 \log \mathrm{cfu} / \mathrm{mL}$ for INIA P678, and $5.77 \pm 0.06 \log$ $\mathrm{cfu} / \mathrm{mL}$ for INIA P734.

** Significant effect $(P<0.01)$ of ripening time.

activity of most bacterial proteinases and peptidases in cheese is close to neutrality (Garde et al., 1997). Also, proteolytic and peptidolytic enzymes from bifidobacteria could influence proteolysis in cheese (Bergamini et al., 2009). In this sense, the increase in proteolysis of Scamorza sheep milk cheese made with bifidobacteria was associated with enzymes of $B$. longum BL-46 and B. lactis BB12 (Albenzio et al., 2013), and a similar result was obtained in Cheddar cheese made with a mix of lactobacilli and bifidobacteria (Ong et al., 2007). Other studies have reported reduced proteolytic activities of bifidobacteria in dairy products (Roy, 2005), of $B$. lactis in a semi-hard cheese model (Bergamini et al., 2009), and of Bifidobacterium bifidum and B. longum in Canestrato Pugliese cheese (Corbo et al., 2001).

In the present study, total FAA concentration was significantly $(P<0.01)$ influenced by the Bifidobacterium strain and ripening time (Table 4$)$. In control cheese, total FAA increased significantly $(P<0.01)$ during ripening. Addition of B. longum INIA P678 and $B$. breve INIA P734 resulted in higher concentrations of total FAA at 28 and $60 \mathrm{~d}$ compared with control cheese. Similarly, contents of free alanine, glutamine, histidine, isoleucine, proline, serine, threonine, tyrosine, and valine at $60 \mathrm{~d}$ were higher $(P<0.01)$ in cheeses with $B$. longum INIA P678 and B. breve INIA P734 than in control cheese. Higher leucine and lysine concentrations were detected at $60 \mathrm{~d}$ in all experimental cheeses compared with control cheese, whereas higher methionine concentration at $60 \mathrm{~d}$ was observed only for B. longum INIA P678 cheese. Despite the low or undetectable counts of this strain, cheese with $B$. longum INIA P678 presented significantly higher overall proteolysis and total FAA levels than control cheese. Bifidobacteria are capable of hydrolyzing products from primary proteolysis to smaller peptides and AA (Ong et al., 2007). Similar to our results, higher levels of free glutamine, serine, arginine, isoleucine, and leucine were reported

Table 3. Overall proteolysis during ripening in control cheese and in cheeses made using bifidobacteria as adjunct cultures ${ }^{1}$

\begin{tabular}{llcccc}
\hline & & & \multicolumn{3}{c}{ Cheese $^{2}$} \\
\cline { 3 - 6 } Variable & Day & Control & INIA P2 & INIA P678 & INIA P734 \\
\cline { 3 - 7 } & 7 & $0.264 \pm 0.017^{\mathrm{a}}$ & $0.277 \pm 0.015^{\mathrm{a}}$ & $0.283 \pm 0.018^{\mathrm{a}}$ & $0.278 \pm 0.008^{\mathrm{a}}$ \\
& 28 & $0.665 \pm 0.021^{\mathrm{a}}$ & $0.730 \pm 0.054^{\mathrm{ab}}$ & $0.800 \pm 0.055^{\mathrm{b}}$ & $0.741 \pm 0.047^{\mathrm{ab}}$ \\
& 60 & $1.400 \pm 0.053^{\mathrm{a}}$ & $1.459 \pm 0.065^{\mathrm{ab}}$ & $1.702 \pm 0.082^{\mathrm{c}}$ & $1.543 \pm 0.057^{\mathrm{b}}$ \\
\hline
\end{tabular}

\footnotetext{
${ }^{a-c}$ Means at each ripening time with different superscripts differ significantly $(P<0.01$, Tukey test).

${ }^{1}$ Mean \pm SD of 4 determinations on 2 cheese-making trials.

${ }^{2}$ Initial inoculum of bifidobacteria in milk was $6.31 \pm 0.17 \log \mathrm{cfu} / \mathrm{mL}$ for INIA P2, $5.01 \pm 0.17 \log \mathrm{cfu} / \mathrm{mL}$ for INIA P678, and $5.77 \pm 0.06 \log$ $\mathrm{cfu} / \mathrm{mL}$ for INIA P734.

**Significant effect $(P<0.01)$ of ripening time.
} 
for ripe Scamorza cheese made with a mix of B. longum and B. lactis than for control cheese (Albenzio et al., 2013).
Organic Acids and Sugar Content. Significant differences $(P<0.01)$ in organic acids content during ripening (Table 5) were recorded between cheeses with

Table 4. Free AA (mg/100 g of cheese DM) during ripening in control cheese and in cheeses made using bifidobacteria as adjunct cultures ${ }^{1}$

\begin{tabular}{|c|c|c|c|c|c|}
\hline \multirow[b]{2}{*}{$\mathrm{AA}$} & \multirow[b]{2}{*}{ Day } & \multicolumn{4}{|c|}{ Cheese $^{2}$} \\
\hline & & Control & INIA P2 & INIA P678 & INIA P734 \\
\hline \multirow[t]{3}{*}{$\overline{\mathrm{Ala}^{* *}}$} & 7 & $11.7 \pm 0.7$ & $10.9 \pm 2.1$ & $12.5 \pm 0.2$ & $11 \pm 1$ \\
\hline & 28 & $18.2 \pm 1.2$ & $14.9 \pm 2.4$ & $20.2 \pm 4.2$ & $17 \pm 4.9$ \\
\hline & 60 & $35.6 \pm 4.2$ & $28.5 \pm 3.2$ & $46.5 \pm 3.7^{\mathrm{a}}$ & $44.4 \pm 8.8^{\mathrm{a}}$ \\
\hline \multirow[t]{3}{*}{$\operatorname{Arg}^{* *}$} & 7 & $54.8 \pm 11.5$ & $48.9 \pm 10.2$ & $44.3 \pm 8.8^{\mathrm{a}}$ & $46.7 \pm 5.1^{\mathrm{a}}$ \\
\hline & 28 & $73.2 \pm 21.9$ & $65.5 \pm 20.4$ & $60 \pm 12.7$ & $68.8 \pm 15.8$ \\
\hline & 60 & $135.7 \pm 35.2$ & $134.7 \pm 23.9$ & $170.5 \pm 45.7$ & $164.5 \pm 78.4$ \\
\hline \multirow[t]{3}{*}{ Cys** } & 7 & $234.1 \pm 18.3$ & $230.2 \pm 11.5$ & $235.4 \pm 28.7$ & $246.1 \pm 12.9$ \\
\hline & 28 & $271.8 \pm 13.1$ & $287.1 \pm 18.9$ & $383.1 \pm 56.2^{\mathrm{a}}$ & $341.5 \pm 30.5^{\mathrm{a}}$ \\
\hline & 60 & $346.5 \pm 93.8$ & $254.4 \pm 23.3$ & $390.5 \pm 70.2$ & $376 \pm 98.4$ \\
\hline \multirow[t]{3}{*}{ Glu** } & 7 & $9.7 \pm 2.1$ & $10 \pm 1.4$ & $13.2 \pm 2.6^{\mathrm{a}}$ & $11.1 \pm 3$ \\
\hline & 28 & $16.9 \pm 5.9$ & $18 \pm 1.8$ & $34.7 \pm 4.1^{\mathrm{a}}$ & $22.4 \pm 3.4^{\mathrm{a}}$ \\
\hline & 60 & $80.8 \pm 11.3$ & $86.6 \pm 15.3$ & $158.9 \pm 13.5^{\mathrm{a}}$ & $108.1 \pm 13.7^{\mathrm{a}}$ \\
\hline \multirow[t]{3}{*}{ His** } & 7 & $13.3 \pm 3$ & $16.4 \pm 2.1$ & $15.8 \pm 3.5$ & $16 \pm 2.6$ \\
\hline & 28 & $29.5 \pm 5.4$ & $26.7 \pm 2.8$ & $39 \pm 2.4^{\mathrm{a}}$ & $31.5 \pm 3.4$ \\
\hline & 60 & $75 \pm 9.5$ & $75.8 \pm 9.4$ & $114 \pm 14^{\mathrm{a}}$ & $91.1 \pm 14.5^{\mathrm{a}}$ \\
\hline \multirow[t]{3}{*}{$\mathrm{Ile}^{* *}$} & 7 & $2.1 \pm 0.5$ & $2.3 \pm 0.4$ & $2.7 \pm 0.2^{\mathrm{a}}$ & $2.1 \pm 0.3$ \\
\hline & 28 & $12.2 \pm 1.8$ & $11.8 \pm 2.1$ & $17.3 \pm 1.6^{\mathrm{a}}$ & $13.9 \pm 0.6^{\mathrm{a}}$ \\
\hline & 60 & $45.5 \pm 2.9$ & $44.8 \pm 8.7$ & $66.7 \pm 7.1^{\mathrm{a}}$ & $54.4 \pm 7.6^{\mathrm{a}}$ \\
\hline \multirow[t]{3}{*}{ Leu** } & 7 & $8.3 \pm 1.2$ & $9.5 \pm 1.3^{\mathrm{a}}$ & $11.6 \pm 0.3^{\mathrm{a}}$ & $9.4 \pm 0.8^{\mathrm{a}}$ \\
\hline & 28 & $38.2 \pm 0.6$ & $44.8 \pm 1.7^{\mathrm{a}}$ & $59.6 \pm 4.1^{\mathrm{a}}$ & $46.8 \pm 0.6^{\mathrm{a}}$ \\
\hline & 60 & $145.7 \pm 12$ & $164.2 \pm 6^{\mathrm{a}}$ & $210.8 \pm 12.2^{\mathrm{a}}$ & $178.2 \pm 7.2^{\mathrm{a}}$ \\
\hline \multirow[t]{3}{*}{ Lys** } & 7 & $22.9 \pm 5.8$ & $20.1 \pm 4$ & $21.9 \pm 5.2$ & $18.1 \pm 7.2$ \\
\hline & 28 & $56.8 \pm 9.1$ & $61.2 \pm 19.6$ & $85.8 \pm 6.4^{\mathrm{a}}$ & $78.1 \pm 2.3^{\mathrm{a}}$ \\
\hline & 60 & $204.2 \pm 7.5$ & $227.8 \pm 24.7^{\mathrm{a}}$ & $261.4 \pm 29.1^{\mathrm{a}}$ & $231.6 \pm 34.2^{\mathrm{a}}$ \\
\hline \multirow{3}{*}{ Met** } & 7 & $3 \pm 0.4$ & $3.1 \pm 1$ & $4.6 \pm 0.9^{\mathrm{a}}$ & $3.6 \pm 0.8$ \\
\hline & 28 & $15.5 \pm 2.2$ & $18.2 \pm 2.4^{\mathrm{a}}$ & $28.3 \pm 6.9^{\mathrm{a}}$ & $21.2 \pm 3.9^{\mathrm{a}}$ \\
\hline & 60 & $67.7 \pm 3.4$ & $72.2 \pm 13.4$ & $98.9 \pm 12.7^{\mathrm{a}}$ & $71.3 \pm 13.5$ \\
\hline \multirow[t]{3}{*}{ Phe** } & 7 & $\mathrm{ND}^{3}$ & ND & ND & ND \\
\hline & 28 & ND & ND & ND & ND \\
\hline & 60 & $141.9 \pm 15.2$ & $159.6 \pm 15.5$ & $206.5 \pm 23.3^{\mathrm{a}}$ & $145.1 \pm 33.5$ \\
\hline \multirow[t]{3}{*}{ Pro** } & 7 & $33.7 \pm 3.5$ & $34.7 \pm 2$ & $35 \pm 2.1$ & $32.9 \pm 4$ \\
\hline & 28 & $43.6 \pm 0.9$ & $36.2 \pm 10.5^{\mathrm{a}}$ & $37.4 \pm 13.2^{\mathrm{a}}$ & $36.6 \pm 13.8^{\mathrm{a}}$ \\
\hline & 60 & $70.9 \pm 10.3$ & $62.6 \pm 2.1$ & $97.8 \pm 1.9^{\mathrm{a}}$ & $87.7 \pm 15.7^{\mathrm{a}}$ \\
\hline \multirow{3}{*}{ Ser** } & 7 & $8.8 \pm 1.2$ & $10.9 \pm 4$ & $12 \pm 1.4^{\mathrm{a}}$ & $8.9 \pm 1.7$ \\
\hline & 28 & $24.5 \pm 4.8$ & $25.5 \pm 1.1$ & $41 \pm 3.3^{\mathrm{a}}$ & $28.4 \pm 2.8$ \\
\hline & 60 & $94.1 \pm 9$ & $92.5 \pm 15$ & $154 \pm 15.7^{\mathrm{a}}$ & $110.6 \pm 4.4^{\mathrm{a}}$ \\
\hline \multirow{3}{*}{ Thr** } & 7 & $6.8 \pm 1.4$ & $7.5 \pm 0.8$ & $6.1 \pm 0.7$ & $5.9 \pm 1$ \\
\hline & 28 & $11.3 \pm 3.2$ & $9.2 \pm 1.6^{\mathrm{a}}$ & $11.5 \pm 0.8$ & $9.7 \pm 0.7^{\mathrm{a}}$ \\
\hline & 60 & $27.7 \pm 8.5$ & $26.1 \pm 8.6$ & $39.7 \pm 9^{\mathrm{a}}$ & $35.7 \pm 14.2^{\mathrm{a}}$ \\
\hline \multirow[t]{3}{*}{ Tyr** } & 7 & $10.2 \pm 1.1$ & $9.9 \pm 1.7$ & $11.4 \pm 0.8$ & $10.9 \pm 1.3$ \\
\hline & 28 & $20.9 \pm 0.8$ & $21.2 \pm 0.8$ & $26.7 \pm 2.3^{\mathrm{a}}$ & $22.8 \pm 0.7^{\mathrm{a}}$ \\
\hline & 60 & $54.9 \pm 4.4$ & $58.2 \pm 7.5$ & $79 \pm 7.3^{\mathrm{a}}$ & $61.6 \pm 4.7^{\mathrm{a}}$ \\
\hline \multirow[t]{3}{*}{$\mathrm{Val}^{* *}$} & 7 & $10.6 \pm 1.9$ & $11.2 \pm 2$ & $15.3 \pm 0.6^{\mathrm{a}}$ & $12.1 \pm 1.2^{\mathrm{a}}$ \\
\hline & 28 & $38 \pm 2.7$ & $40 \pm 2.2^{\mathrm{a}}$ & $63.4 \pm 1.1^{\mathrm{a}}$ & $49.1 \pm 5.1^{\mathrm{a}}$ \\
\hline & 60 & $110.3 \pm 9.3$ & $110.7 \pm 4.3$ & $165.6 \pm 4.8^{\mathrm{a}}$ & $141.5 \pm 4.3^{\mathrm{a}}$ \\
\hline \multirow{3}{*}{ Total** } & 7 & $430 \pm 40.9$ & $425.6 \pm 26.7$ & $442 \pm 30.3$ & $434.9 \pm 20.7$ \\
\hline & 28 & $670.5 \pm 49.4$ & $680.2 \pm 29.4$ & $908.1 \pm 63.9^{\mathrm{a}}$ & $787.7 \pm 39.4^{\mathrm{a}}$ \\
\hline & 60 & $1,636.5 \pm 97.6$ & $1,598.6 \pm 122.2$ & $2,260.7 \pm 165^{\mathrm{a}}$ & $1901.9 \pm 181.4$ \\
\hline
\end{tabular}

${ }^{a}$ Means at each ripening time followed by a superscript are significantly different $(P<0.01$, Dunnett test) from the control cheese.

${ }^{1}$ Mean \pm SD of duplicate determinations in 2 cheese-making experiments.

${ }^{2}$ Initial inoculum of bifidobacteria in milk was $6.31 \pm 0.17 \mathrm{log} \mathrm{cfu} / \mathrm{mL}$ for INIA P2, $5.01 \pm 0.17 \mathrm{log} \mathrm{cfu} / \mathrm{mL}$ for INIA P678, and $5.77 \pm 0.06 \log \mathrm{cfu} / \mathrm{mL}$ for INIA P734.

${ }^{3} \mathrm{ND}=$ not detected.

**Significant effect $(P<0.01)$ of ripening time. 
Bifidobacterium strains and control cheese. Cheeses with B. pseudolongum INIA P2 showed higher levels of citric, uric, and butyric acids and lower levels of pyruvic and acetic acids than control cheese at $\mathrm{d} 7$ or 28 but not at $\mathrm{d} 60$. Cheeses with $B$. longum INIA P678 had higher levels of acetic and butyric acids and lower levels of citric and lactic acids at $\mathrm{d} 60$ with respect to control cheese. Cheeses with $B$. breve INIA P734 showed higher levels of citric and uric acids all throughout ripening and of butyric acid at d 28 compared with control cheese and lower levels of acetic acid until d 28 and of lactic acid at d 60. Contents of lactic, citric, and acetic acids were similar to values reported in Manchego cheese by Garde et al. (2012), although in our work a higher amount of butyric acid was observed and propionic acid was not detected. Higher concentrations of acetic acid during ripening of cheeses containing bifidobacteria were also observed by Ong et al. (2007) and related to their metabolism. In our study, there was not a marked increase of the level of acetic acid in cheeses with bifidobacteria, which is important in terms of sensory properties (Madureira et al., 2013). On the other hand, the increase in short-chain fatty acids observed in cheeses with Bifidobacterium strains revealed their ability to produce these compounds in food and possibly in the intestine. Short-chain fatty acids produced by gut microorganisms play a pivotal role in gastrointestinal functionality, immune regulation, and host metabolism and could counteract stress-induced brain-gut axis alteration (van de Wouw et al., 2018).

Lactose and glucose were below detection level in all cheeses as early as d 7 (Table 5), which makes these

Table 5. Organic acids and sugars (mg/100 g of cheese DM) during ripening in control cheese and in cheeses made using bifidobacteria as adjunct cultures ${ }^{1}$

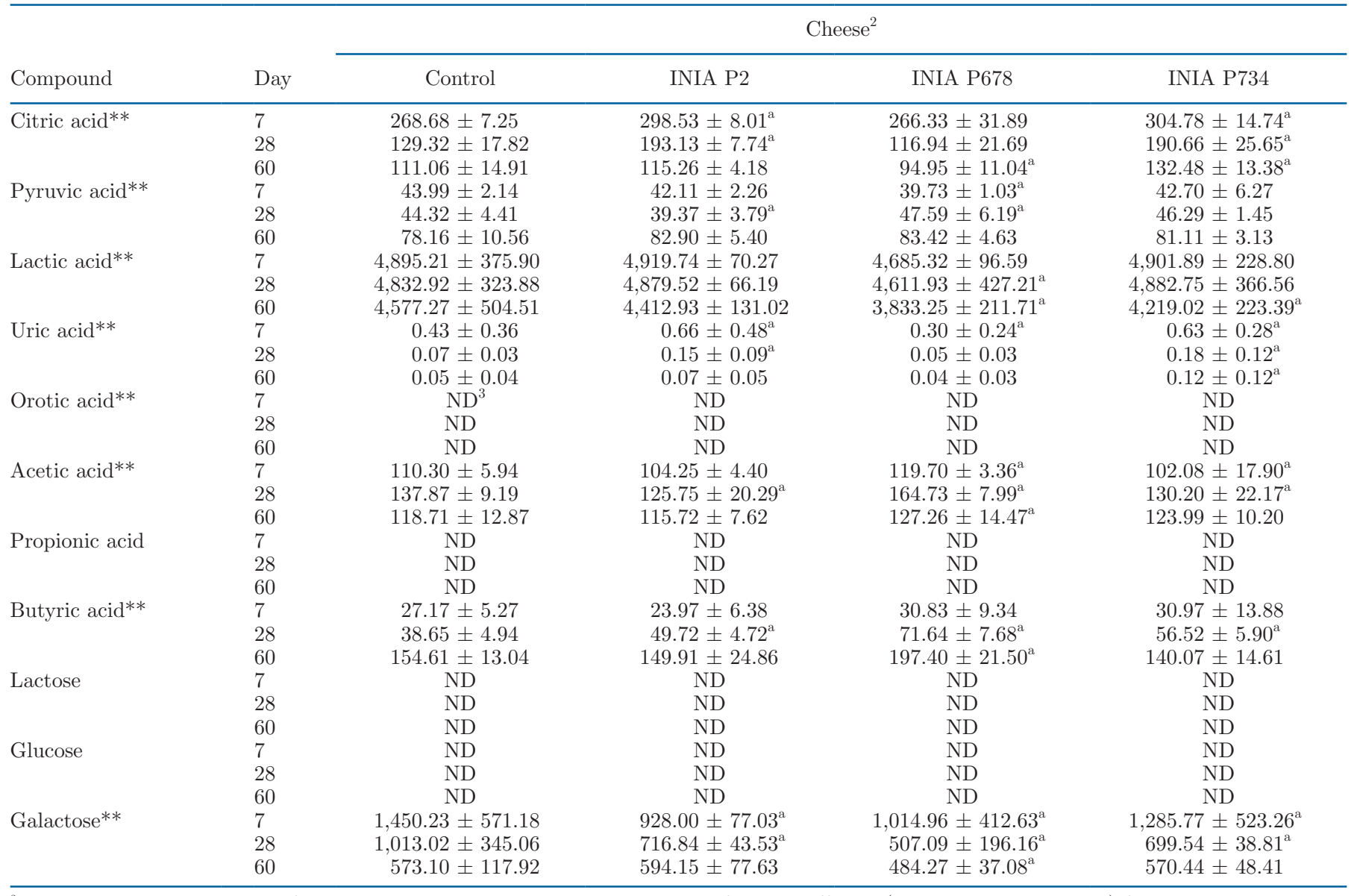

${ }^{\mathrm{a}}$ Means at each ripening time followed by a superscript in each row are significantly different $(P<0.01$, Dunnett test $)$ from the control cheese. ${ }^{1}$ Mean \pm SD of duplicate determinations in 2 cheese-making experiments.

${ }^{2}$ Initial inoculum of bifidobacteria in milk was $6.31 \pm 0.17 \log \mathrm{cfu} / \mathrm{mL}$ for INIA P2, $5.01 \pm 0.17 \log \mathrm{cfu} / \mathrm{mL}$ for INIA P678, and $5.77 \pm 0.06 \log$ $\mathrm{cfu} / \mathrm{mL}$ for INIA P734.

${ }^{3} \mathrm{ND}=$ not detected.

** Significant effect $(P<0.01)$ of ripening time. 
cheeses of interest for people with lactose intolerance and is in agreement with their abundance of organic acids. Galactose concentration was lower $(P<0.01)$ at $\mathrm{d} 7$ and 28 in all cheeses containing Bifidobacterium than in control cheese and at d 60 only in cheese made with B. longum INIA P678.

Volatile Compounds. Volatile analysis detected 32 compounds, including aldehydes, ketones, alcohols, acids, esters, alkanes, hydrocarbons, and sulfur compounds (Supplemental Table S1, https://doi.org/10 $.3168 /$ jds.2020-18203), of which 29 compounds varied significantly $(P<0.01)$ with ripening time. Several volatile compounds considered key odorants in cheese (e.g., 2-butanone, acetic acid, hexanoic acid, 1-propanol, and 2-pentanol) were detected in this work, suggesting their importance in the distinctive flavor of sheep semi-hard cheese (Ávila et al., 2017). The same volatile compounds were detected in cheeses made with Bifidobacterium strains and in control cheese. There were no significant differences in the levels of volatile compounds between cheeses at d 28 and 60 except for 2 -pentanol, which exhibited significantly $(P<0.01)$ lower values in cheeses made with Bifidobacterium strains than in control cheese.

Although a significant increase in FAA concentration was observed in cheeses with B. longum INIA P678 and $B$. breve INIA P734, this increase had no unfavorable effect on the levels of volatile compounds. On the other hand, cheeses with $B$. longum INIA P678 presented higher $(P<0.01)$ concentrations of pyruvic, acetic, and butyric acids than control cheese throughout ripening. The increase in pyruvic and butyric acids could be considered a potential probiotic finding of interest in the human colon. Pyruvate is the central point of butyrate synthesis and precursor for acetate formation. Butyrate is the main energy source of colonic epithelial cells and plays an important role in gastrointestinal homeosta- sis and as a preventive agent of intestinal pathologies (Muñoz-Tamayo et al., 2011).

\section{Sensory Evaluation}

Color Characteristics. Values of $L^{*}, a^{*}$, and $b^{*}$ color parameters after 7,28 , and $60 \mathrm{~d}$ of ripening were not affected by the addition of any of the Bifidobacterium strains (Supplemental Table S2, https://doi .org/10.3168/jds.2020-18203). The $L^{*}$ and $a^{*}$ values of cheeses decreased $(P<0.01)$ during ripening because of the increase in DM content, as described previously (Ávila et al., 2008). All cheeses showed negative $a^{*}$ values in all cases, in the greenish direction, whereas $b^{*}$ values were positive, in the yellowish direction, and increased with ripening time due to chemical reactions (Mortensen et al., 2004).

Instrumental Texture. Fracturability, hardness, and elasticity of cheeses (Table 6) increased significantly $(P<0.01)$ during ripening according to ANOVA results, probably because of the strengthening effect of moisture loss during ripening, as reported previously (Picon et al., 2010). The 3 rheological characteristics were also influenced by the addition of Bifidobacterium strains $(P<0.01)$ according to ANOVA results. Only INIA P734 cheese showed significant differences $(P<$ 0.01 ) with respect to control cheese for the 3 texture parameters after 7 or $28 \mathrm{~d}$ of ripening.

Sensory Evaluation. Trained panelists noticed a significant $(P<0.01)$ effect of ripening time with increases in odor intensity, aroma intensity, and taste intensity as ripening progressed according to the ANOVA, which was accompanied by a significant $(P<$ 0.01 ) effect on aroma quality, taste quality, and texture quality, the values of which also increased over ripening (Table 7$)$. There were also significant $(P<0.01)$ effects of ripening time on acidic taste, which decreased, and

Table 6. Texture parameters during ripening in control cheese and in cheeses made using bifidobacteria as adjunct cultures ${ }^{1}$

\begin{tabular}{|c|c|c|c|c|c|}
\hline Parameter & Day & \multicolumn{4}{|c|}{ Cheese $^{2}$} \\
\hline \multirow[t]{2}{*}{ Fracturability** $(\mathrm{N})$} & 7 & $29.170 \pm 8.380$ & $26.318 \pm 1.364$ & $27.626 \pm 3.931$ & $22.738 \pm 3.219$ \\
\hline & 60 & $36.842 \pm 6.130$ & $35.789 \pm 6.216$ & $35.268 \pm 5.484$ & $31.877 \pm 6.522$ \\
\hline \multirow[t]{2}{*}{ Hardness** $(\mathrm{J})$} & 7 & $0.198 \pm 0.057$ & $0.181 \pm 0.034$ & $0.161 \pm 0.024$ & $0.152 \pm 0.027$ \\
\hline & 28 & $0.283 \pm 0.073$ & $0.280 \pm 0.063$ & $0.256 \pm 0.043$ & $0.211 \pm 0.048$ \\
\hline \multirow{2}{*}{ Elasticity** $\left(\mathrm{N} / \mathrm{mm}^{2}\right)$} & 28 & $0.719 \pm 0.329$ & $0.742 \pm 0.339$ & $0.558 \pm 0.190$ & $0.522 \pm 0.206$ \\
\hline & 60 & $1.028 \pm 0.290$ & $1.064 \pm 0.301$ & $0.817 \pm 0.288$ & $0.889 \pm 0.308$ \\
\hline
\end{tabular}

\footnotetext{
${ }^{1}$ Mean \pm SD of 6 determinations on 2 cheese-making trials.

${ }^{2}$ Initial inoculum of bifidobacteria in milk was $6.31 \pm 0.17 \log \mathrm{cfu} / \mathrm{mL}$ for INIA P2, $5.01 \pm 0.17 \log \mathrm{cfu} / \mathrm{mL}$ for INIA P678, and $5.77 \pm 0.06 \log$ $\mathrm{cfu} / \mathrm{mL}$ for INIA P734.

** Significant effect $(P<0.01)$ of ripening time.
} 
Table 7. Sensory evaluation during ripening in control cheese and in cheeses made using bifidobacteria as adjunct cultures ${ }^{1}$

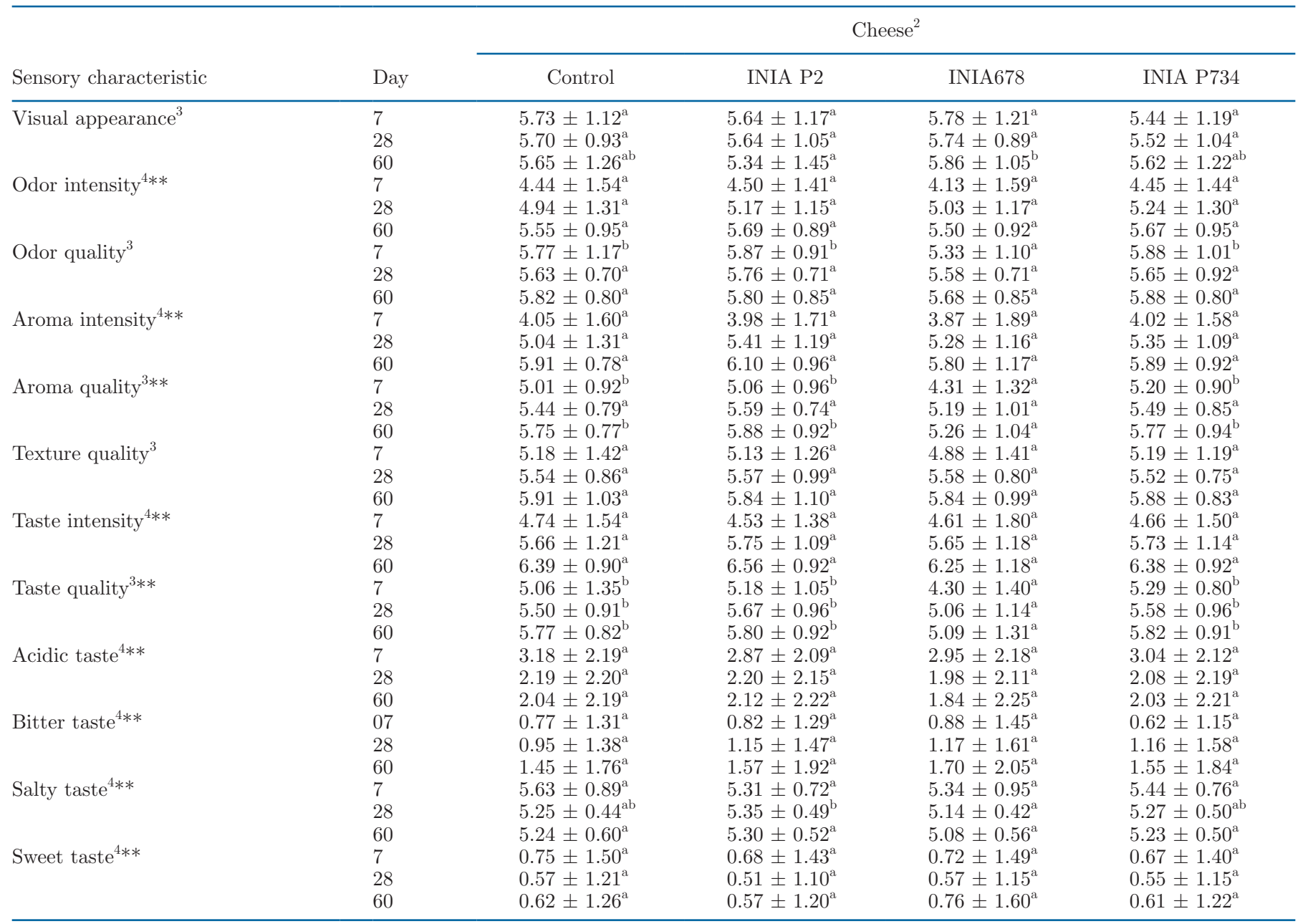

\footnotetext{
$\mathrm{cfu} / \mathrm{mL}$ for INIA P734.

${ }^{3}$ Scale from 0 ("I dislike it") to 10 ("I like it").

${ }^{4}$ Scale from 0 (very weak) to 10 (very strong).

**Significant effect $(P<0.01)$ of ripening time.
}

$\overline{\mathrm{a}, \mathrm{b}}$ Means at each ripening time with different superscripts differ significantly $(P<0.01$, Tukey test).

${ }^{1}$ Mean \pm SD from 16 trained panelists of duplicate determinations on 2 cheese-making trials.

${ }^{2}$ Initial inoculum of bifidobacteria in milk was $6.31 \pm 0.17 \log \mathrm{cfu} / \mathrm{mL}$ for INIA P2, $5.01 \pm 0.17 \log \mathrm{cfu} / \mathrm{mL}$ for INIA P678, and $5.77 \pm 0.06 \log$

on bitter taste, which increased. No significant effect of ripening time was found for visual appearance or for the other taste descriptors. Our results agree with those obtained by Bergamini et al. (2009) in semi-hard cheeses made with mixed cultures, which included $B$. lactis.

In the present study, B. longum INIA P678 counts markedly declined during ripening, and the cheeses made with this strain received significantly $(P<0.01)$ lower aroma quality and taste quality scores than the rest at almost all sampling times, which may hinder its use as an adjunct probiotic culture. Bifidobacterium breve INIA P734 exhibited a high survival rate until d 28 , and the sensory characteristics of cheeses made with this strain did not differ from those of control cheese. Therefore, it may be considered of technological interest as an adjunct probiotic culture for cheese. Bifidobacterium pseudolongum INIA P2, which showed the highest survival rates during cheese ripening, and even after simulated gastrointestinal conditions, did not affect the sensory characteristics of cheese at any of the sampling times. Therefore, it offers considerable interest for use as an adjunct probiotic culture for cheese.

\section{CONCLUSIONS}

Marked differences in the survival of the 3 Bifidobacterium strains during cheese ripening and after further 
simulated gastrointestinal digestion were observed in the present study, the highest survival rates being those of B. pseudolongum INIA P2. There were also differences between the 3 Bifidobacterium strains regarding the chemical changes in cheeses leading to the formation of FAA, organic acids, and volatile compounds. Those differences influenced the sensory characteristics of cheeses with Bifidobacterium with respect to control cheese. Taking into account the highest survival rates and the sensory characteristics of cheeses, B. pseudolongum INIA P2 was considered the most adequate strain for use as an adjunct probiotic culture in the manufacture of fresh and semi-hard sheep milk cheeses. Further work is needed to evaluate the probiotic activity of sheep milk cheeses made using these Bifidobacterium strains as adjunct cultures in assays carried out with animals and humans.

\section{ACKNOWLEDGMENTS}

This work was supported by projects RM2010-0000800-00 and RTA2013-00029-00-00 from the Spanish Ministry of Economy and Competitiveness (MINECO; Madrid, Spain). The authors have not stated any conflicts of interest.

\section{REFERENCES}

Albenzio, M., A. Santillo, M. Caroprese, A. Braghieri, A. Sevi, and F. Napolitano. 2013. Composition and sensory profiling of probiotic Scamorza ewe milk cheese. J. Dairy Sci. 96:2792-2800. https://doi .org/10.3168/jds.2012-6273.

Albenzio, M., A. Santillo, R. Marino, A. Della Malva, M. Caroprese, and A. Sevi. 2015. Identification of peptides in functional Scamorza ovine milk cheese. J. Dairy Sci. 98:8428-8432. https://doi.org/ $10.3168 /$ jds.2015-9844.

AOAC. 1984. Official Methods of Analysis. 14th ed. AOAC, Washington, DC.

Ávila, M., S. Garde, and M. Nuñez. 2008. The influence of some manufacturing and ripening parameters on the colour of ewes' milk cheese. Milchwissenschaft 63:160-164.

Ávila, M., N. Gómez-Torres, D. Delgado, P. Gaya, and S. Garde. 2016. Application of high pressure processing for controlling Clostridium tyrobutyricum and late blowing defect on semi-hard cheese. Food Microbiol. 60:165-173. https://doi.org/10.1016/j.fm.2016.07.008.

Ávila, M., N. Gómez-Torres, D. Delgado, P. Gaya, and S. Garde. 2017. Effect of high-pressure treatments on proteolysis, volatile compounds, texture, colour, and sensory characteristics of semi-hard raw ewe milk cheese. Food Res. Int. 100:595-602. https://doi.org/ 10.1016/j.foodres.2017.07.043.

Barbosa, I. C., M. E. Oliveira, M. S. Madruga, B. Gullón, M. T. Pacheco, A. M. Gomes, A. S. Batista, M. M. Pintado, E. L. Souza, and R. C. Queiroga. 2016. Influence of the addition of Lactobacillus acidophilus La-05, Bifidobacterium animalis ssp. lactis Bb-12 and inulin on the technological, physicochemical, microbiological and sensory features of creamy goat cheese. Food Funct. 7:43564371. https://doi.org/10.1039/C6FO00657D.

Bergamini, C. V., E. R. Hynes, S. B. Palma, N. G. Sabbag, and C. A. Zalazar. 2009. Proteolytic activity of three probiotic strains in semi-hard cheese as single and mixed cultures: Lactobacillus acidophilus, Lactobacillus paracasei and Bifidobacterium lactis.
Int. Dairy J. 19:467-475. https://doi.org/10.1016/j.idairyj.2009.02 .008 .

Bérodier, F., P. Lavanchy, M. Zannoni, J. Casals, L. Herrero, and C. Adamo. 1997. Guide d'evaluation olfato-gustative des fromages à pâte dure et semi-dure. Lebensm. Wiss. Technol. 30:653-664. https://doi.org/10.1006/fstl.1996.0235.

Bouzas, J., C. A. Kantt, F. Bodyfelt, and J. A. Torres. 1991. Simultaneous determination of sugars and organic acids in Cheddar cheese by high-performance liquid chromatography. J. Food Sci 56:276-278. https://doi.org/10.1111/j.1365-2621.1991.tb08034.x.

Boylston, T. D., C. G. Vinderola, H. B. Ghoddusi, and J. A. Reinheimer. 2004. Incorporation of bifidobacteria into cheeses: Challenges and rewards. Int. Dairy J. 14:375-387. https://doi.org/10 .1016/j.idairyj.2003.08.008.

Carmody, R. N., J. E. Bisanz, B. P. Bowen, M. F. Maurice, S. Lyalina, K. B. Louie, D. Treen, K. S. Chadaideh, V. Maini Rekdal, E. N. Bess, P. Spanogiannopoulos, Q. Y. Ang, K. C. Bauer, T. W. Balon, K. S. Pollard, T. R. Northen, and P. J. Turnbaugh. 2019. Cooking shapes the structure and function of the gut microbiome. Nat. Microbiol. 4:2052-2063. https://doi.org/10.1038/s41564-019 $-0569-4$.

Church, F. C., H. E. Swaisgood, D. H. Porter, and G. L. Catignani. 1983. Spectrophotometric assay using o-phthaldialdehyde for determination of proteolysis in milk and isolated milk proteins. J. Dairy Sci. 66:1219-1227. https://doi.org/10.3168/jds.S0022 -0302(83)81926-2.

Cohen, S. A., and D. P. Michaud. 1993. Synthesis of a fluorescent derivatizing reagent, 6-aminoquinolyl-N-hydroxysuccinimidyl carbamate, and its application for the analysis of hydrolysate amino acids via high-performance liquid chromatography. Anal. Biochem. 211:279-287. https://doi.org/10.1006/abio.1993.1270.

Collado, M. C., Y. Moreno, J. M. Cobo, J. A. Mateos, and M. Hernández. 2006. Molecular detection of Bifidobacterium animalis DN173010 in human feces during fermented milk administration. Food Res. Int. 39:530-535. https://doi.org/10.1016/j.foodres.2005 .10 .011 .

Corbo, M. R., M. Albenzio, M. De Angelis, A. Sevi, and M. Gobbetti. 2001. Microbiological and biochemical properties of Canestrato Pugliese hard cheese supplemented with bifidobacteria. J. Dairy Sci. 84:551-561. https://doi.org/10.3168/jds.S0022-0302(01)74507 $-9$.

Cuffia, F., C. Bergamini, and M. Candioti. 2018. Probiotic soft sheep's cheese: Evaluation of probiotic survival and its influence on proteolysis and organoleptic characteristics. Int. Food Res. J. 25:399407. http://www.ifrj.upm.edu.my/25\%20(01)\%202018/(53).pdf.

del Pozo, B. S. F., P. Gaya, M. Medina, M. A. Rodríguez-Marín, and M. Nuñez. 1988. Changes in chemical and rheological characteristics of La Serena ewes' milk cheese during ripening. J. Dairy Res. 55:457-464. https://doi.org/10.1017/S0022029900028715.

du Toit, E., S. Vesterlund, M. Gueimonde, and S. Salminen. 2013. Assessment of the effect of stress-tolerance acquisition on some basic characteristics of specific probiotics. Int. J. Food Microbiol. 165:51-56. https://doi.org/10.1016/j.ijfoodmicro.2013.04.022.

Garde, S., M. Ávila, P. Gaya, R. Arias, and M. Nuñez. 2012. Sugars and organic acids in raw and pasteurized milk Manchego cheeses with different degrees of late blowing defect. Int. Dairy J. 25:8791. https://doi.org/10.1016/j.idairyj.2012.01.005.

Garde, S., P. Gaya, M. Medina, and M. Nuñez. 1997. Acceleration of flavour formation in cheese by a bacteriocin-producing adjunct lactic culture. Biotechnol. Lett. 19:1011-1014. https://doi.org/10 .1023/A:1018451401925.

Gomes, A. M. P., and F. X. Malcata. 1999. Bifidobacterium spp. and Lactobacillus acidophilus: Biological, biochemical, technological and therapeutical properties relevant for use as probiotics. Trends Food Sci. Technol. 10:139-157. https://doi.org/10.1016/S0924 $-2244(99) 00033-3$

Gómez-Torres, N., M. Ávila, P. Gaya, and S. Garde. 2014. Prevention of late blowing defect by reuterin produced in cheese by a Lactobacillus reuteri adjunct. Food Microbiol. 42:82-88. https://doi.org/ 10.1016/j.fm.2014.02.018. 
Gómez-Torres, N., S. Garde, A. Peirotén, and M. Ávila. 2015. Impact of Clostridium spp. on cheese characteristics: Microbiology, color formation of volatile compounds and off-flavors. Food Control 56:186-194. https://doi.org/10.1016/j.foodcont.2015.03.025.

Granata, M., G. Brandi, A. Borsari, R. Gasbarri, and D. Di Gioia. 2013. Synbiotic yogurt consumption by healthy adults and the elderly: The fate of bifidobacteria and LGG probiotic strain. Int. J. Food Sci. Nutr. 64:162-168. https://doi.org/10.3109/09637486 2012.718742 .

Granato, D., F. B. Branco, A. G. Cruz, J. A. F. Faria, and N. P. Shah. 2010. Probiotic dairy products as functional foods. Compr. Rev. Food Sci. Food Saf. 9:455-470. https://doi.org/10.1111/j.1541 $-4337.2010 .00120 . x$.

Karimi, R., A. M. Mortazavian, and A. Gomes Da Cruz. 2011. Viability of probiotic microorganisms in cheese during production and storage: A review. Dairy Sci. Technol. 91:283-308. https://doi.org/ 10.1007/s13594-011-0005-x.

Kehagias, C., J. Csapó, S. Konteles, E. Kolokitha, S. Koulouris, and Z. Csapó-Kiss. 2008. Support of growth and formation of d-amino acids by Bifidobacterium longum in cows', ewes', goats' milk and modified whey powder products. Int. Dairy J. 18:396-402. https:/ /doi.org/10.1016/j.idairyj.2007.11.014.

Kim, G. B., S. H. Yi, and B. H. Lee. 2004. Purification and characterization of three different types of bile salt hydrolases from Bifidobacterium strains. J. Dairy Sci. 87:258-266. https://doi.org/ 10.3168/jds.S0022-0302(04)73164-1.

Krause, I., A. Bockhardt, H. Neckermann, T. Henle, and H. Klostermeyer. 1995. Simultaneous determination of amino acids and biogenic amines by reversed-phase high-performance liquid chromatography of the dabsyl derivatives. J. Chromatogr. A 715:67-79. https: / doi.org/10.1016/0021-9673(95)00578-B.

Lugli, G. A., S. Duranti, K. Albert, L. Mancabelli, S. Napoli, A. Viappiani, R. Anzalone, G. Longhi, C. Milani, F. Turroni, G. Alessandri, D. Sela, D. van Sinderen, and M. Ventura. 2019. Unveiling genomic diversity among members of the species Bifidobacterium pseudolongum, a widely distributed gut commensal of the animal kingdom. Appl. Environ. Microbiol. 85:e03065-18. https://doi.org/ 10.1128/AEM.03065-18.

Madureira, A. R., J. C. Soares, M. Amorim, T. Tavares, A. M. Gomes, M. M. Pintado, and F. X. Malcata. 2013. Bioactivity of probiotic whey cheese: Characterization of the content of peptides and organic acids. J. Sci. Food Agric. 93:1458-1465. https://doi.org/10 $.1002 /$ jsfa. 5915 .

Mills, S., C. Stanton, J. A. Lane, G. J. Smith, and P. Ross. 2019. Precision nutrition and the microbiome, part I: Current state of the science. Nutrients 11:923. https://doi.org/10.3390/nu11040923.

Mortensen, G., G. Bertelsen, B. K. Mortensen, and H. Stapelfeldt. 2004. Light-induced changes in packaged cheeses - A review. Int. Dairy J. 14:85-102. https://doi.org/10.1016/S0958-6946(03)00169 $-9$.

Muñoz-Tamayo, R., B. Laroche, E. Walter, J. Doré, S. H. Duncan, H. J. Flint, and M. Leclerc. 2011. Kinetic modelling of lactate utilization and butyrate production by key human colonic bacterial species. FEMS Microbiol. Ecol. 76:615-624. https://doi.org/10.1111/ j.1574-6941.2011.01085.x.

O'Callaghan, M., and D. van Sinderen. 2016. Bifidobacteria and their role as members of the human gut microbiota. Front. Microbiol. 7:925. https://doi.org/10.3389/fmicb.2016.00925

Ong, L., A. Henriksson, and N. P. Shah. 2007. Chemical analysis and sensory evaluation of Cheddar cheese produced with Lactobacillus acidophilus, Lb. casei, Lb. paracasei or Bifidobacterium sp. Int. Dairy J. 17:937-945. https://doi.org/10.1016/j.idairyj.2007.01 .002 .

Peirotén, A., J. L. Arqués, M. Medina, and E. Rodríguez-Mínguez. 2018. Bifidobacterial strains shared by mother and child as source of probiotics. Benef. Microbes 9:231-238. https://doi.org/10.3920/ BM2017.0133.
Peirotén, A., P. Gaya, I. Älvarez, D. Bravo, and J. M. Landete. 2019a. Influence of different lignin compounds on enterolignan production by Bifidobacterium and Lactobacillus strains. Int. J. Food Microbiol. 289:17-23. https://doi.org/10.1016/j.ijfoodmicro.2018.08.028.

Peirotén, A., P. Gaya, J. L. Arqués, M. Medina, and E. Rodríguez. 2019b. Technological properties of bifidobacterial strains shared by mother and child. Biomed. Res. Int. 2019:9814623. https://doi .org/10.1155/2019/9814623.

Picon, A., P. Gaya, E. Fernandez-Garcia, A. Rivas-Canedo, M. Ávila, and M. Nuñez. 2010. Proteolysis, lipolysis, volatile compounds, texture, and flavor of Hispánico cheese made using frozen ewe milk curds pressed for different times. J. Dairy Sci. 93:2896-2905. https: //doi.org/10.3168/jds.2009-3041.

Pulina, G., M. J. Milan, M. P. Lavin, A. Theodoridis, E. Morin, J. Capote, D. L. Thomas, A. H. D. Francesconi, and G. Caja. 2018. Current production trends, farm structures, and economics of the dairy sheep and goat sectors. J. Dairy Sci. 101:6715-6729. https:/ /doi.org/10.3168/jds.2017-14015.

Reid, G. 2015. The growth potential for dairy probiotics. Int. Dairy J. 49:16-22. https://doi.org/10.1016/j.idairyj.2015.04.004.

Rodríguez, E., J. L. Arqués, R. Rodríguez, A. Peirotén, J. M. Landete, and M. Medina. 2012. Antimicrobial properties of probiotic strains isolated from breast-fed infants. J. Funct. Foods 4:542-551. https: //doi.org/10.1016/j.jff.2012.02.015.

Roy, D. 2005. Technological aspects related to the use of bifidobacteria in dairy products. Lait 85:39-56. https://doi.org/10.1051/lait: 2004026.

Ruiz, L., A. Margolles, and B. Sánchez. 2013. Bile resistance mechanisms in Lactobacillus and Bifidobacterium. Front. Microbiol. 4:396. https://doi.org/10.3389/fmicb.2013.00396.

Ruiz, L., P. Ruas-Madiedo, M. Gueimonde, C. G. de los Reyes-Gavilán, A. Margolles, and B. Sánchez. 2011. How do bifidobacteria counteract environmental challenges? Mechanisms involved and physiological consequences. Genes Nutr. 6:307-318. https://doi .org/10.1007/s12263-010-0207-5.

Saarela, M., I. Virkajarvi, H. L. Alakomi, P. Sigvart-Mattila, and J. Mättö. 2006. Stability and functionality of freeze-dried probiotic Bifidobacterium cells during storage in juice and milk. Int. Dairy J. 16:1477-1482. https://doi.org/10.1016/j.idairyj.2005.12.007.

Sanlier, N., B. B. Gökcen, and A. C. Sezgin. 2019. Health benefits of fermented foods. Crit. Rev. Food Sci. Nutr. 59:506-527. https:// doi.org/10.1080/10408398.2017.1383355.

Song, M., W. S. Park, J. Yoo, G.-S. Han, B.-M. Kim, P.-N. Seong, M.H. Oh, K.-W. Kim, and J.-S. Ham. 2017. Characteristics of Kwark cheese supplemented with Bifidobacterium longum KACC 91563. Korean J. Food Sci. Anim. Resour. 37:773-779. https://doi.org/10 .5851/kosfa.2017.37.5.773.

Sonnenburg, E. D., and J. L. Sonnenburg. 2019. The ancestral and industrialized gut microbiota and implications for human health. Nat. Rev. Microbiol. 17:383-390. https://doi.org/10.1038/s41579 $-019-0191-8$

Souza, T. C., A. M. Silva, J. R. P. Drews, D. A. Gomes, C. G. Vinderola, and J. R. Nicoli. 2013. In vitro evaluation of Bifidobacterium strains of human origin for potential use in probiotic functional foods. Benef. Microbes 4:179-186. https://doi.org/10.3920/ BM2012.0052.

van de Wouw, M., M. Boehme, J. M. Lyte, N. Wiley, C. Strain, O. O'Sullivan, G. Clarke, C. Stanton, T. G. Dinan, and J. F. Cryan. 2018. Short-chain fatty acids: Microbial metabolites that alleviate stress-induced brain-gut axis alterations. J. Physiol. 596:49234944. https://doi.org/10.1113/JP276431.

Vinderola, G., M. F. Zacarías, W. Bockelmann, H. Neve, J. Reinheimer, and K. J. Heller. 2012. Preservation of functionality of Bifidobacterium animalis ssp. lactis INL1 after incorporation of freeze-dried cells into different food matrices. Food Microbiol. 30:274-280. https://doi.org/10.1016/j.fm.2011.12.004. 